\title{
Targeting early B-cell receptor signaling induces apoptosis in leukemic mantle cell lymphoma
}

\author{
Mohand-Akli Boukhiar ${ }^{1,2}$, Claudine Roger ${ }^{3}$, Julie Tran ${ }^{3}$, Remy Gressin ${ }^{5,6,7}$, Antoine Martin 1,2,4,7, \\ Florence Ajchenbaum-Cymbalista ${ }^{1,2,3}$, Nadine Varin-Blank ${ }^{1,2}$, Dominique Ledoux ${ }^{1,2,7}$ and Fanny Baran-Marszak ${ }^{1,2,3,7^{*}}$
}

\begin{abstract}
Background: We previously showed that B-cell receptor (BCR) signaling pathways are important for in vitro survival of mantle cell lymphoma (MCL) cells. To further identify early BCR-activated signaling pathways involved in MCL cell survival, we focused our study on BCR-proximal kinases such as LYN whose dysregulations could contribute to the aggressive course of MCL.

Methods: Primary MCL cells were isolated from 14 leukemic patients. Early BCR-induced genes were identified by qRT-PCR array. The basal and BCR-induced phosphorylation of LYN and JNK were evaluated by immunoblottting. Cell survival signals were evaluated by apoptosis using flow cytometry.

Results: We showed that LYN was constitutively phosphorylated in MCL cell lines and in 9/10 leukemic MCL cases. Treatment with dasatinib or with a specific inhibitor of Src kinases such as PP2 suppressed constitutive LYN activation and increased in vitro spontaneous apoptosis of primary $M C L$ cells. BCR engagement resulted in an increase of LYN phosphorylation leading to activation of c-JUN NH2-terminal kinase (JNK) and over-expression of the early growth response gene-1 (EGR-1). Inhibition of JNK with SP600125 induced apoptosis and reduced level of basal and BCR-induced expression of EGR-1. Furthermore, decreasing EGR1 expression by siRNA reduced BCRinduced cell survival. Treatment with PP2 or with dasatinib suppressed BCR-induced LYN and JNK phosphorylation as well as EGR-1 upregulation and is associated with a decrease of cell survival in all cases analysed.
\end{abstract}

Conclusions: This study highlights the importance of BCR signaling in MCL cell survival and points out to the efficiency of kinase inhibitors in suppressing proximal BCR signaling events and in inducing apoptosis.

Keywords: Mantle cell lymphoma, LYN, BCR, EGR-1, Dasatinib

\section{Background}

Mantle cell lymphoma (MCL) constitutes about 6\%-10\% of non-Hodgkin lymphoma and despite recent advances in the treatment, the disease has not generally been cured with a poor progression-free survival for a large number of patients. New therapies that target specific signaling molecules are therefore of potential value. In recent years, some studies tried to reveal new suitable therapeutic targets [1-9] and have clarified the impact of several signaling pathways for increased proliferation and resistance to apoptosis of MCL cells. Constitutively

\footnotetext{
* Correspondence: fanny.baran-marszak@avc.aphp.fr

'INSERM, UMR U978, Adaptateur de Signalisation en Hématologie, Bobigny F-93000, France

${ }^{2}$ Université Paris 13, Sorbonne Paris Cité, Labex INFLAMEX, Bobigny F-93000, France

Full list of author information is available at the end of the article
}

active B-cell receptor (BCR)-mediated signaling has been implicated in the pathogenesis of a number of NHLs including diffuse large B cell lymphoma (DLBCL), follicular lymphoma, gastric mucosa-associated lymphoid tissue lymphoma and B-cell chronic lymphocytic leukaemia (CLL) [10-13]. Recently, we demonstrated in primary MCL cells a central role for active BCR signals in survival of MCL cells [14]. The activated forms of the BCR-associated kinases LYN and spleen tyrosine kinase (SYK) were present in MCL tumor tissues therefore supporting an in vivo role of active BCR signaling in this pathology [15]. Moreover, MCL is characterized by a highly restricted immunoglobulin gene repertoire with stereotyped VH CDR3s and precise Somatic Hyper Mutation targeting, thus strongly

\section{() Biomed Central}


implying a role for antigen-driven selection of the clonogenic progenitors [16].

Upon antigen engagement, $\operatorname{Ig} \alpha-\operatorname{Ig} \beta$ heterodimer (CD79a-CD79b) are phosphorylated on immunoreceptor tyrosine-based activation motif (ITAM) tyrosines by the BCR-associated kinase LYN, which belongs to the Src family kinases (SFK). SYK protein is then recruited through its $\mathrm{SH} 2$ domain to the phosphorylated $\operatorname{Ig} \alpha-\operatorname{Ig} \beta$ heterodimer, resulting in the triggering of different signaling cascades [17]. Among them, the PLC $2 / \mathrm{PKC}$ pathway is crucial for activation of various mitogenactivated protein kinases (MAPKs), such as extracellular signal-regulated kinase (ERK) and c-JUN NH2-terminal kinase (JNK). Extensive work by several groups has established that MAP kinase pathways play critical roles in the pathogenesis of various hematologic malignancies, providing new potential molecular targets for future therapeutic approaches [18]. Indeed, gene expression profiling of DLBCL revealed enhanced expression of JNK mRNA in at least 60 percent of cases [19]. Moreover inhibition of JNK activation by the pharmacological inhibitor SP600125 induced growth arrest in myeloma cell lines [20]. Of interest, JNK was showed to be constitutively activated in MCL and inhibition of phosphoJNK with SP600125 resulted in growth arrest in MCL cell lines (Jeko-1, HBL-2, UPN-1, Granta-519) [21].

A key downstream target of JNK activation is the early growth response gene-1 (EGR-1) transcription factor playing an important role in cell cycle regulation, cell proliferation and apoptosis [22,23]. EGR-1 was first identified as a putative G0/G1 switch regulatory gene in lymphocyte cultures [24]. Constitutive EGR-1 expression is involved in the self-renewal capacity of B-1 lymphocytes [25] and hematopoietic stem cells [26]. EGR-1 is also constitutively expressed in immature BKS2 B lymphoma and inhibition of EGR-1 using specific antisense oligonucleotides induced apoptosis [22]. Alternatively, mature B2 cells undergo proliferation with an increase of EGR-1 expression upon BCR engagement [25]. Moreover, EGR-1 is down-regulated upon JNK inhibition by SP600125, and its overexpression partially protects against JNK inhibitor-induced apoptosis in B lymphoma cell lines [27].

Given the importance of BCR signaling in tumor cell survival including MCL cells, we hypothesized that targeting BCR-associated kinases such as SFK represents a potentially useful strategy to treat MCL. LYN kinase is the major SFK expressed in B cells and its constitutive phosphorylation was previously reported in Jeko-1 cell line [28]. However its role in MCL has not yet been explored to date. Therefore we analysed the activation status of LYN in primary MCL cells and evaluated the in vitro impact of its inhibition on MCL cells survival. We showed that LYN was constitutively phosphorylated in most MCL cases tested and that BCR engagement led to an increased LYN phosphorylation. Treatment with dasatinib, the oral broad inhibitor of tyrosine kinases, suppressed BCR-induced LYN and JNK phosphorylation in primary MCL cells. Similarly, treatment with dasatinib inhibited BCR-dependent EGR-1 upregulation and cell survival. Using PP2, a more specific inhibitor of BCRassociated SFK, we proved the efficiency of blocking BCRemanating signals in suppressing MCL cell survival.

\section{Results}

\section{EGR-1 and c-MYC are rapidly induced upon BCR} engagement in $\mathrm{MCL}$

We have previously described that BCR engagement induces a survival signal in MCL through an IL6/IL10dependent activation-loop of STAT3 [14]. To further investigate which $\mathrm{BCR}$-induced signaling pathways are critical, we screened purified B cells from primary leukemic MCL for the differential expression of 84 genes upon anti-IgM stimulation using $\mathrm{RT}^{2}$ Profiler PCR Arrays (SA Biosciences PAHS-027). Fifteen genes exhibited significant increased or decreased expression as compared to unstimulated cells (Additional file 1: Table S2; average fold-change from 4 individual experiments using UPN 5, 10, 13 and 14). Four genes were down-regulated (APAF1, CCNG2, ATM, BTG2), all corresponding to proapoptotic proteins. Conversely, eleven genes were overexpressed (CDK4, MCL1, NFkB1, IFNB1, SESN2, BCL2A, IL6, TNF, HK2, EGR-1, c-MYC), all of them being involved in cell cycle progression or inhibition of apoptosis. Within this group, three genes encoded for transcription factors; namely NF-kB, c-MYC and EGR-1 the two later being the two most upregulated genes upon anti-IgM stimulation (average of 23.6- and 17.6-fold increase, respectively).

BCR-induced expressions of c-MYC and EGR-1 were then confirmed by kinetic experiments in MCL cell lines (Granta-519 and HBL-2) (Figure 1A and B) and in MCL patients' samples (Figure 1C). For MCL cell lines, basal levels of EGR-1 mRNA was rapidly increased within $30 \mathrm{~min}$ upon BCR ligation, peaked at $1 \mathrm{~h}$ and gradually returned to basal level within 3 to 6 hours. Similarly, EGR-1 protein levels increased upon anti-IgM stimulation and returned to basal level within 6 h (Figure 1B). A similar increase was observed for primary cells (UPN7 and UPN10) with EGR-1 proteins still detectable at 6 hours (Figure 1C). C-MYC expression was significantly induced upon BCR engagement in patients' cells only (Figure 1A for Granta-519 and HBL-2 cells, Figure $1 \mathrm{C}$ for UPN7). The pattern of c-MYC mRNA induction differed from that of EGR-1 and displayed a constant increase at least up to $3 \mathrm{~h}$ associated with an increase of c-MYC protein (Figure 1C). We next evaluated the impact of BCR stimulation on a series of 7 patients' samples (Figure 1D). Upon $1 \mathrm{~h}$ of anti-IgM stimulation, EGR-1 mRNA expression was highly upregulated in 4 out of 7 cases 
A

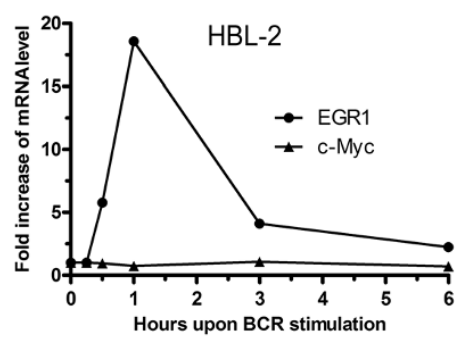

B

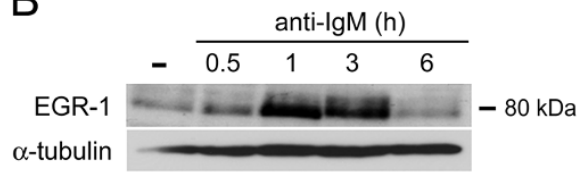

HBL-2

C

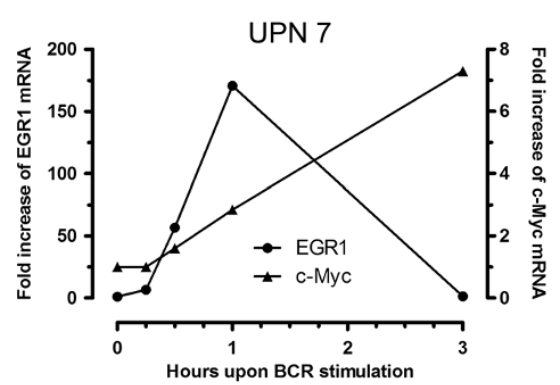

D

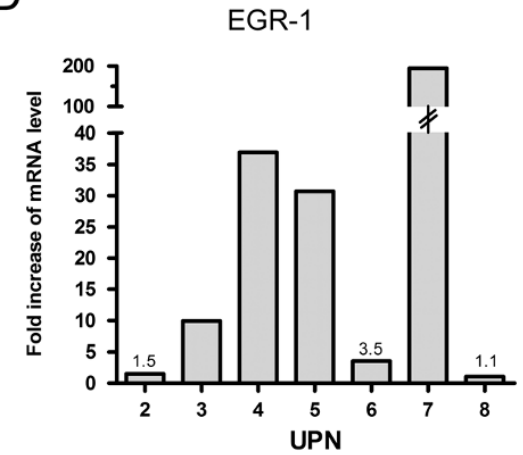

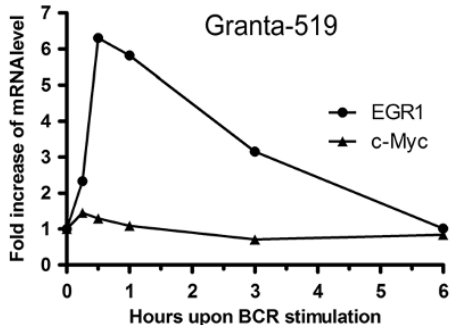

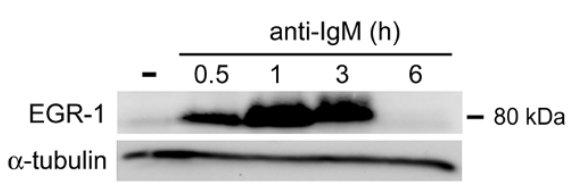

Granta-519
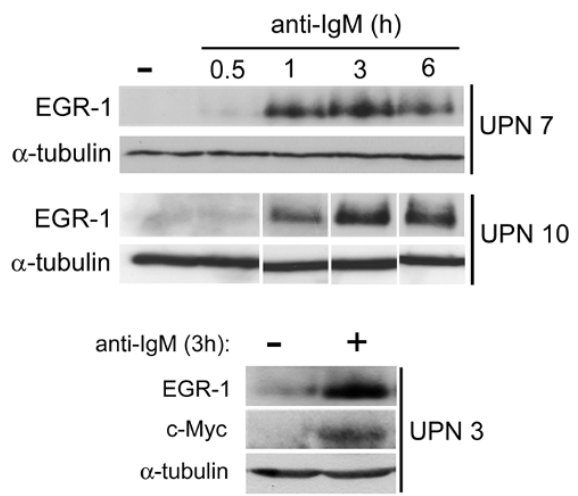

c-Myc

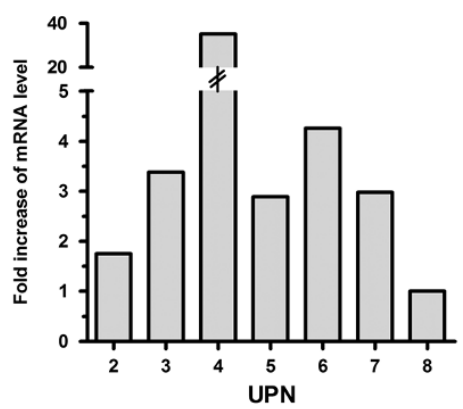

Figure 1 Kinetics of BCR-induced expressions of EGR-1 and c-MYC in MCL cell lines and primary MCL cells. (A) Kinetics of BCR-induced mRNA expression of EGR-1 and c-MYC in Granta-519 and HBL-2 cell lines. $3 \times 10^{6}$ cells $/ \mathrm{ml}$ were stimulated with $10 \mu \mathrm{gg} / \mathrm{ml}$ of immobilized anti-lgM antibody for $15 \mathrm{~min}, 30 \mathrm{~min}, 1 \mathrm{~h}, 3 \mathrm{~h}$ and $6 \mathrm{~h}$. EGR-1 and c-MYC expressions were analyzed by qRT-PCR. (B) Induction of EGR-1 protein upon BCR engagement was confirmed by western-blot. (C) The same experiments were performed on primary patients' cells. EGR-1 and c-MYC expressions were analyzed by qRT-PCR (left panel) and western-blot (right panels). (D) EGR-1 and c-MYC mRNA expressions upon anti-lgM stimulation (1 h) were analyzed by qRT-PCR from 7 patients' samples (UPN2, 3, 4, 5, 6, 7 and 8). Fold increase of mRNA level were calculated compared with unstimulated cells in all experiments. All measurements were done in duplicate and the mean is provided.

and clearly with a major extent as compared to induction of c-MYC (median fold increase: 30.1 and 2.98 for EGR-1 and c-MYC respectively). No correlation was observed between IGHV mutational status and intensity of BCR-induced responses (not shown).
Inhibition of JNK suppresses both BCR-induced EGR-1 upregulation and cell survival

Since EGR-1 has been described as a downstream target of JNK activation in various cellular models, we analyzed in MCL the involvement of JNK in the BCR-induced 
upregulation of EGR-1 and its role on MCL cell survival. In a characteristic patient sample (UPN9), basal JNK phosphorylation was slightly detected and was further enhanced following $5 \mathrm{~min}$ of BCR ligation with higher increase of phospho-JNK p46 (Figure 2A). Moreover, increase of BCRinduced phospho-JNK p46 was fully abolished in the presence of a selective inhibitor of JNK (SP600125, $20 \mu \mathrm{M})$ (Figure 2A). Inhibition of JNK by SP600125 induced a rapid down-regulation of EGR-1 mRNA expression in HBL-2 and Granta-519 cells associated with a subsequent decrease of EGR-1 protein (Figure 2B). Moreover, treatment with SP600125 upon anti-IgM stimulation also led to a blockade of BCR-induced EGR-1 upregulation in MCL cell lines (HBL-2 and Granta-519) and in primary MCL cells (UPN1)
(Figure 2C). To confirm that EGR-1 was a downstream target of JNK in response to BCR activation, anti-IgMstimulated HBL-2 cells were incubated with 5Z-7Oxozeanol, an inhibitor of the transforming growth factor- $\beta$ activated kinase-1 (TAK1) that is critical for BCR-induced JNK activation in B cells [29]. As shown in Additional file 2: Figure S1, treatment with 5Z-7-Oxozeanol $(0.5 \mu \mathrm{M})$ completely abrogated BCR-induced upregulation of EGR-1. Overall, these results indicate that constitutive and BCR-induced EGR-1 expressions are dependent on JNK activation in MCL cells.

We next investigated the impact of JNK inhibition on MCL cell survival. Treatment of HBL-2 and Granta-519 cells with SP600125 for $48 \mathrm{~h}$ increased apoptosis (from 27\%

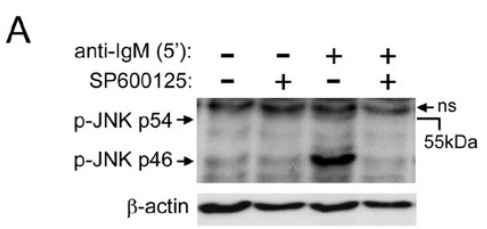

B
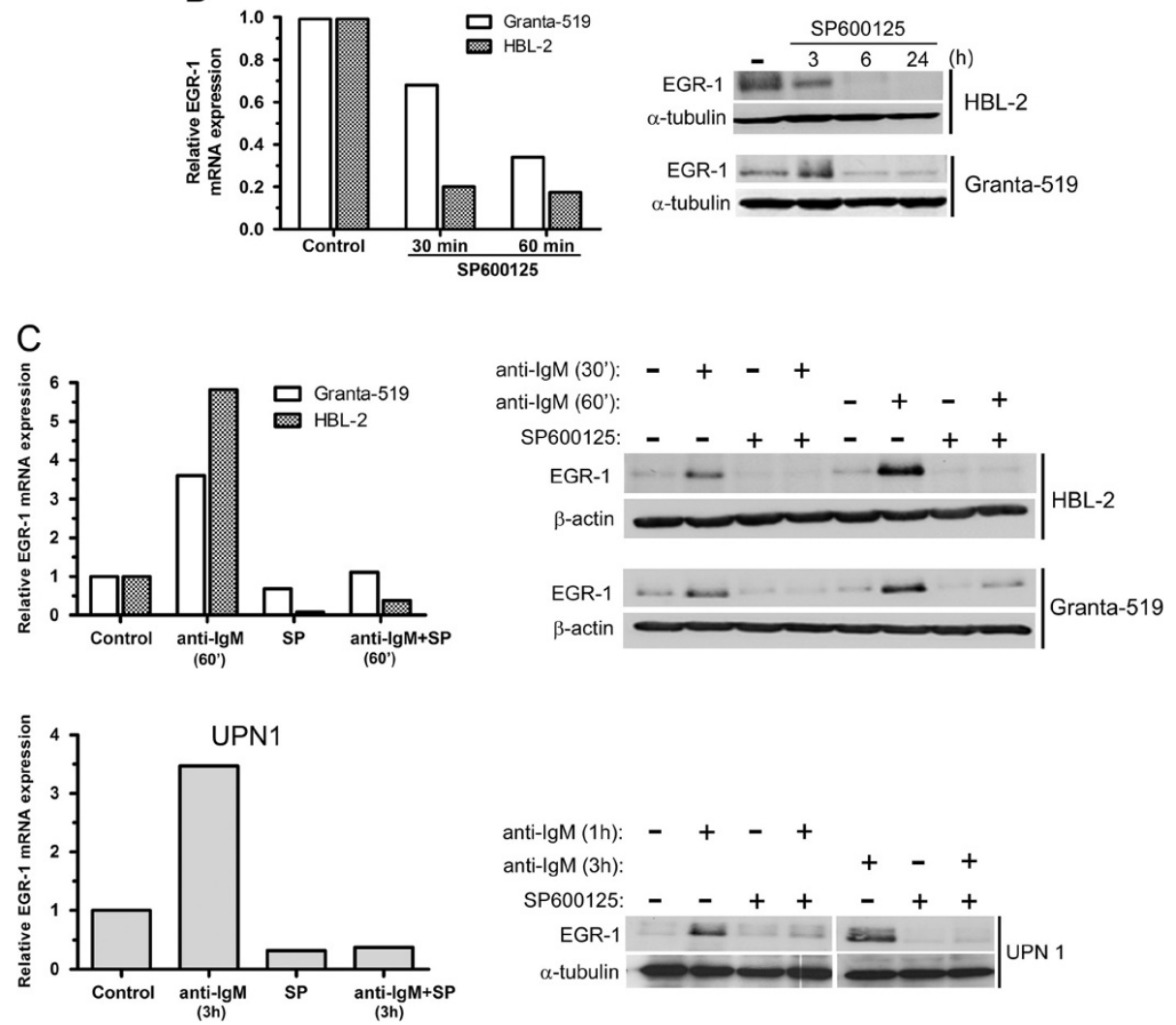

Figure 2 Basal and BCR-induced EGR-1 expressions are dependent on JNK activation. (A) Primary cells (UPN9) were pretreated with SP600125 (10 $\mu \mathrm{M})$ for 1 hour and then stimulated with soluble anti-lgM antibody $(10 \mu \mathrm{g} / \mathrm{ml})$ for $5 \mathrm{~min}$. Basal and BCR-induced phosphorylation of JNK (p54 and p46) were analyzed by western-blot. ns: non specific band. (B) Treatment with SP600125 led to a time-dependent decrease of mRNA and protein EGR-1 levels in Granta-519 and HBL-2 cells. (C) Impact of SP600125 on BCR-induced EGR-1 expression. Granta-519, HBL-2 and primary cells (UPN1) were pretreated with SP600125 for $1 \mathrm{~h}$ and then stimulated with immobilized anti-lgM antibody. EGR-1 mRNA and protein levels were analyzed by qRT-PCR and western-blot respectively. Fold increase of mRNA level were calculated relative to unstimulated cells in all experiments. All measurements were done in duplicate and the mean is provided. 
and $34 \%$ to $68 \%$ and $61 \%$ of apoptotic cells for HBL-2 and Granta-519, respectively) (Figure 3A). A similar increase of apoptosis was observed in MCL primary cells (36 $\pm 5 \%$ and $50 \pm 3 \%$ for untreated and treated cells respectively, $n=4$ ) (Figure 3B). Moreover, BCR engagement induced in most cases a significant inhibition of spontaneous apoptosis $(p=0.039)$ that was abrogated by a treatment with SP600125 $(\mathrm{p}=0.009)$ (Figure 3B). To confirm the involvement of EGR1 in BCR-induced cell survival, MCL primary cells transfected with EGR-1 siRNA were stimulated with antiIgM. As shown in Figure 3C, a reduction of $20 \%$ to $30 \%$ of cell survival was observed as compared to transfection with
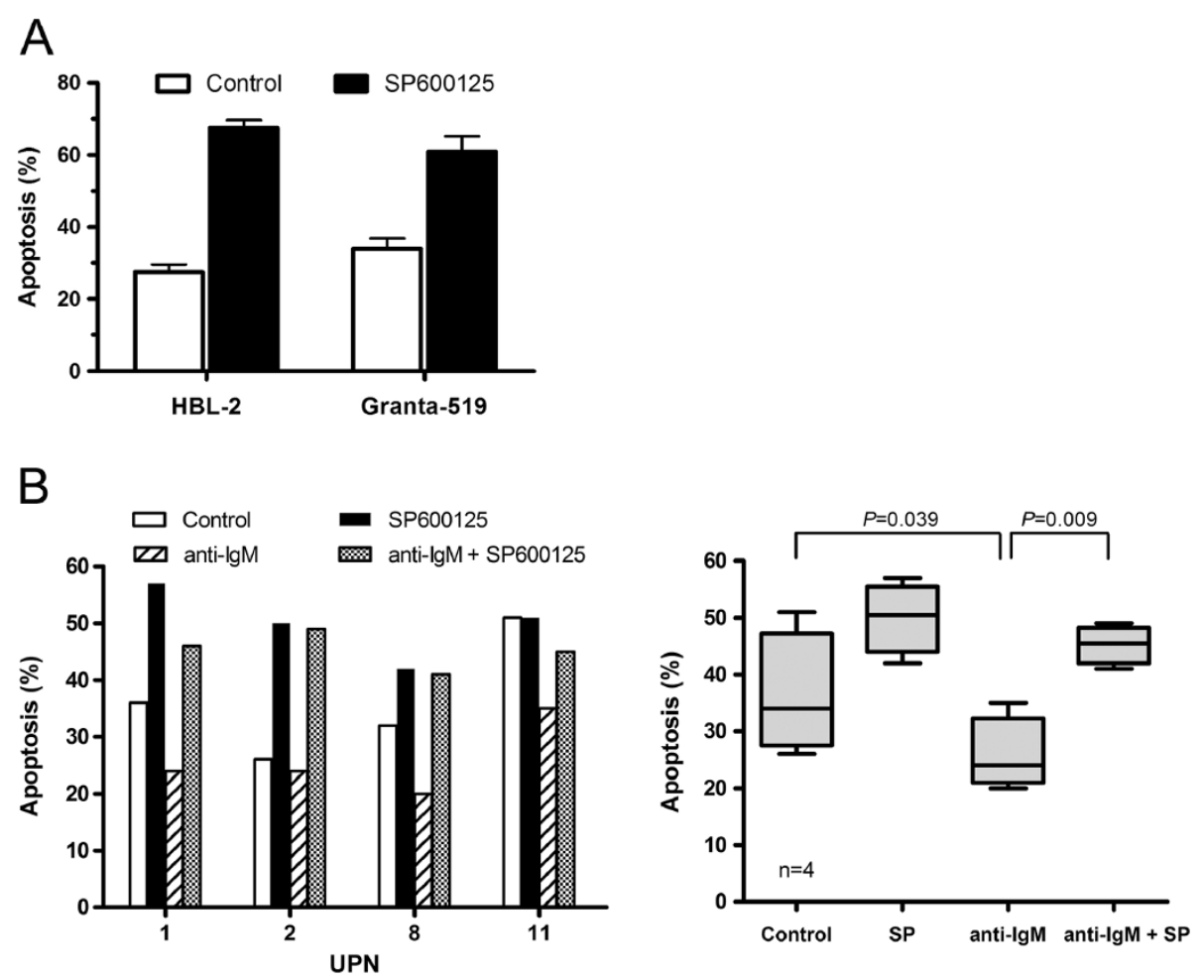

C

Jeko-1

UPN9
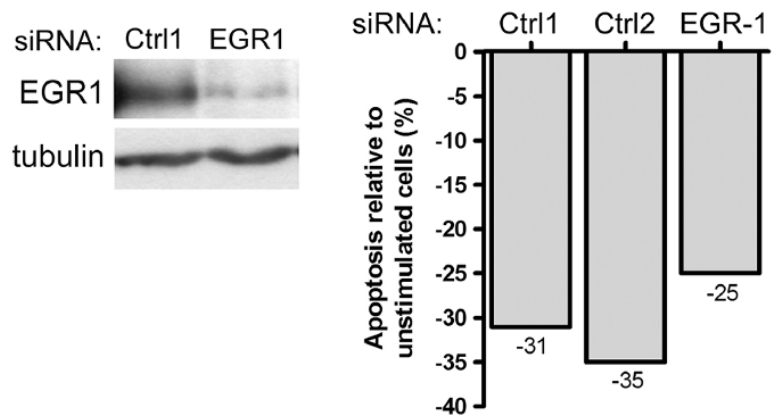

Figure 3 Targeting JNK and EGR-1 induces MCL apoptosis and decreases BCR-induced cell survival. (A) HBL-2 and Granta-519 cells were treated with SP600125 for $48 \mathrm{~h}$ and apoptosis was measured by flow cytometry. Percentage of apoptotic cells corresponded to\% of annexin Vpositive, including PI-negative and PI-positive cells. Mean \pm SD of 2 independent experiments is represented. (B) Patients' cells (UPN1, 2, 8 and 11) were stimulated with immobilized anti-IgM for $24 \mathrm{~h}$ with or without SP600125 (10 $\mu \mathrm{M})$ and the percentage of apoptotic cells was determined by flow cytometry after gating on CD19+ cells (left panel). All measurements were done in duplicate and the mean is provided. Results are also shown as median \pm quartile (box) $\pm \mathrm{SE}$ (bars) $(\mathrm{n}=4$ ) (right panel). Differences between groups were determined using the paired Student $t$ test. (C) Jeko-1 cells were transfected either with control siRNA (Ctrl1) or EGR-1 siRNA and EGR1 protein level was determined by western-blot after $72 \mathrm{~h}$ of culture (left pane). Primary MCL cells (UPN9) were transfected either with controls siRNA (Ctrl1, Ctrl2) or EGR-1 siRNA and subsequently stimulated with anti-lgM for $24 \mathrm{~h}$ or left unstimulated (right panel). Percentage of apoptotic cells was normalized to unstimulated cells and calculated as follows: [(\% apoptosis BCR stimulated cells -\% apoptosis BCR-unstimulated cells) / (\% apoptosis BCR-unstimulated cells)] x100. All measurements were done in duplicate and the mean value is provided. 
control siRNA. Collectively, these results indicate that EGR1 is a downstream target of JNK in MCL cells and that JNK promoted constitutive and BCR-induced cell survival in MCL implicating notably EGR-1 induction.

\section{Inhibition of LYN activity is associated with an increase of apoptosis in MCL cells}

The BCR signal is initially transmitted by LYN kinase leading to activation of various signaling pathways including JNK. We therefore evaluated the activation status of LYN in MCL cells and its involvement in cell survival. Using an anti-phospho-SFK recognizing the catalytic site of several Src kinases among which the Tyr397 of LYN, we detected in 9 out of 10 UPN cases tested (UPN 1,3,5,7,8,9,10,13,14) such a specific signal to variable extents of constitutive phosphorylation forming a 53-56 kDa doublet (Figure 4A and Additional file 3: Figure S2). We confirmed that this doublet corresponded to phospho-LYN by an immunoprecipitation assay using an anti-LYN antibody (Figure 4B). Considering the constitutive activation of LYN in MCL cells, we next evaluated the impact of PP2, a synthetic pyrazolopyrimidine selective inhibitor of SFK, and dasatinib (BMS-354825), an oral multi kinase inhibitor which also inhibits the transautophosphorylation of the active Tyr397 residue of LYN [30]. Treatment of primary cells with PP2 or dasatinib led to a dose-dependent decrease of Tyr397 LYN phosphorylation and complete inhibition was achieved up to $10 \mu \mathrm{M}$ and 100nM for PP2 and dasatinib respectively (Figure 4C). Inhibition of phospho-Tyr397 LYN by PP2 was associated with a significant and dose-dependent increase of apoptosis rate (from $49 \pm 4 \%$ to $67 \pm 3 \%$ apoptotic cells for untreated and $24 \mathrm{~h}$ treated $(10 \mu \mathrm{M})$ cells respectively; $\mathrm{p}=0.006 ; \mathrm{n}=6$ ) (Figure 4D). Treatment with dasatinib for $24 \mathrm{~h}$ also led to a significant and dose-dependent increase of apoptosis (from $46 \pm 5 \%$ to $64 \pm 5 \%$ apoptotic cells for untreated and treated $(100 \mathrm{nM})$ cells, respectively; $\mathrm{p}=0.0001$; $\mathrm{n}=7$ ) (Figure 4E). Remarkably, dasatinib had little apoptosis effect on phospho-Tyr397 LYN-negative cells (UPN4) at a concentration up to $200 \mathrm{nM}$ (Figure 4E, top panel). Altogether, these results indicate that MCL cells display a constitutive phosphorylation of BCR-associated LYN and that treatment with dasatinib or PP2 suppressed LYN activation and increased spontaneous apoptosis.

\section{Inhibition of the BCR-induced LYN phosphorylation by PP2 or dasatinib is associated with a suppression of BCR- mediated cell survival}

Since PP2 and dasatinib efficiently blocked activation of BCR-associated LYN in MCL cells, we next evaluated the impact of these compounds on JNK phosphorylation, EGR-1 expression and on cell survival upon BCR engagement. As shown in Figure 5A, a strong increase of phospho-Tyr397 LYN was observed in response to BCR ligation (lane 1 compared to lane 4) and treatment with dasatinib (100nM) completely blocked this effect while SP600125 that affect JNK did not. Similarly, PP2 decreased BCR-induced phospho-Tyr397 LYN in primary MCL cells (Figure 5B). Dasatinib also reduced BCR-induced phospho-JNK p46 (Figure 5C, lane 1 compared to lane 3 and lane 4 compared to lane 6), positioning JNK as a downstream target of LYN in response to $B C R$ engagement. We next evaluated the impact of dasatinib on basal and BCR-induced level of EGR-1 as a target of JNK. As shown in Figure 5D (left panels), dasatinib (100nM) decreased basal expression of EGR1 mRNA and totally abrogated its upregulation in response to BCR ligation (UPN3, UPN13). Dasatinib also slightly decreased basal level of EGR1 protein and blocked its BCR-induced upregulation (Figure 5D, right panels and Additional file 4: Figure S3). Finally, we evaluated the impact of PP2 and dasatinib treatment on BCR-induced cell survival. Increasing concentrations of dasatinib abrogated the BCR-induced survival response in a dose-dependent manner and significantly suppressed this survival signal in all UPN cases tested (from $34 \pm 6 \%$ to $54 \pm 7 \%$ apoptotic cells for untreated and dasatinibtreated BCR-activated cells, respectively; $n=6 ; \mathrm{p}<0.001$ ) (Figure 6A). Similarly, PP2 treatment also reduced or abolished BCR-induced cell survival (Figure 6B). Overall, these results highlight the importance of LYN, JNK and EGR1 as intermediates of BCR signaling in mediating survival signals in MCL cells and point out to the efficiency of dasatinib in suppressing cell survival signal emanating from the BCR.

\section{Discussion}

In the present study, we showed that primary MCL cells displayed a constitutive and BCR-induced activation of LYN and that treatment with dasatinib or with a more specific inhibitor of LYN suppressed both BCR-induced JNK phosphorylation and EGR-1 upregulation and is associated with a decrease of cell survival.

Recent studies have shown the importance of tonic BCR signaling in survival of DLBCL cells [10] and CLL cells [11] but few studies focused on the role of BCR signaling in MCL cell survival $[14,15]$. We have previously shown in MCL cells that BCR engagement induced a cell survival signal through an IL6/IL10 autocrine dependent activation of STAT3 [14]. To further identify early genes involved in BCR-induced survival, we looked at the differential gene expression upon BCR stimulation. We evidenced that $\mathrm{BCR}$ engagement led to a rapid but transient induction of mRNA and protein levels of EGR-1. EGR-1 is a zinc finger transcription factor whose expression has been described as directly dependent on antigen receptor signaling [31,32]. EGR-1 is a downstream target of JNK and it regulates the expression of several genes 


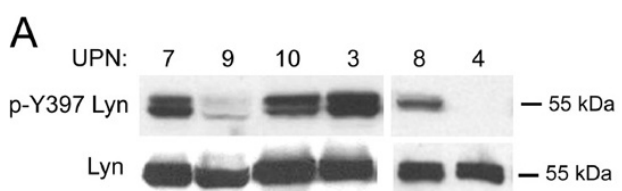

B

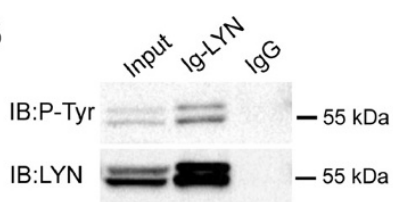

C
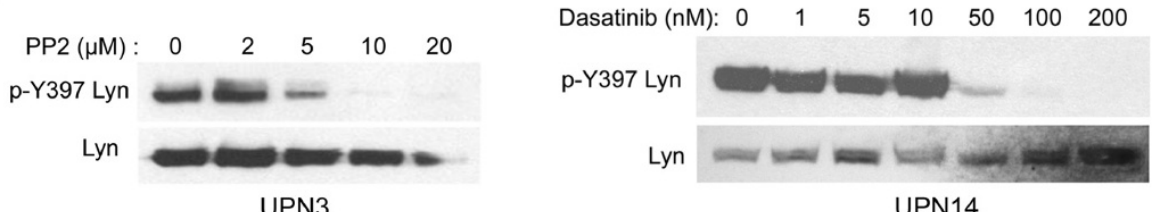

D

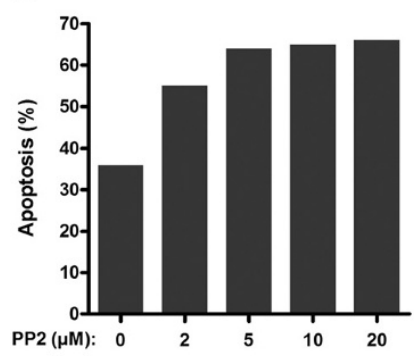

$\mathrm{E}$
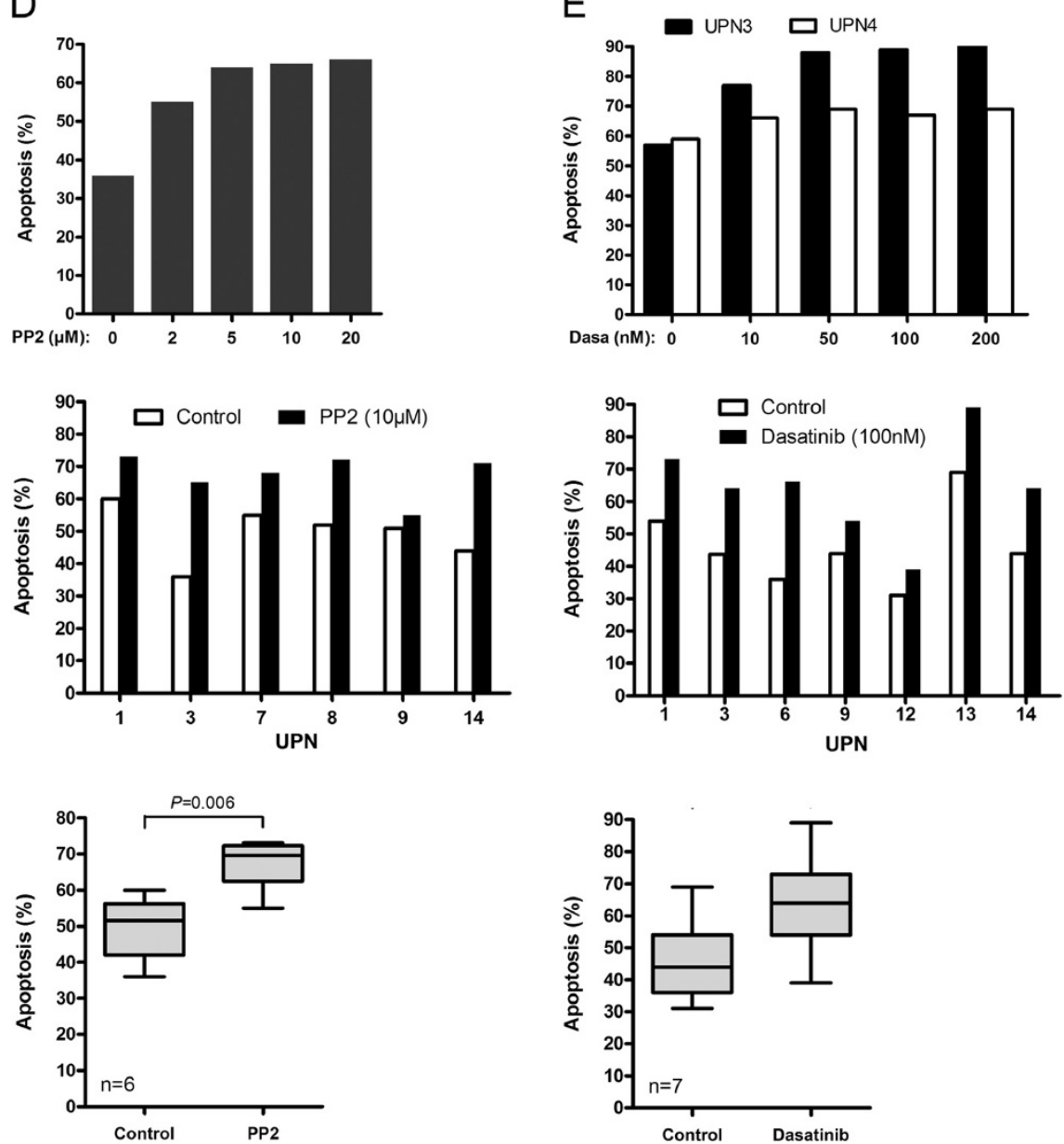

Figure 4 PP2 and dasatinib inhibit constitutive phosphorylation of LYN and induce apoptosis of primary MCL cells. (A) Constitutive phosphorylation profiles of LYN in MCL patients' samples. Phospho-Tyr397 LYN was detected using a pan phospho-src family antibody. The blots were stripped and re-probed for total LYN. (B) Total proteins from HBL-2 cells were immunoprecipitated with an anti LYN antibody (Ig-LYN) or with an irrelevant lgG control and immunobloted (IB) with either an anti-phosphotyrosine antibody (P-Tyr) or an anti-LYN antibody. (C) Primary MCL cells (UPN3, UPN14) were treated with variable concentrations of PP2 (2 to $20 \mu \mathrm{M}$ ) or dasatinib (1 to 200nM) for 2 h. Phospho-Tyr397 LYN and LYN total were analyzed by western-blot. (D) Primary MCL cells were treated with various concentrations of PP2 (UPN3, top panel) or $10 \mu \mathrm{M}$ of PP2 (UPN 1-3-7-8-9-14, middle panel) for $24 \mathrm{~h}$ and apoptosis was measured by flow cytometry after gating on CD19+ cells. All measurements were done in duplicate and the mean is provided. Results are also shown as median \pm quartile (box) $\pm \mathrm{SE}$ (bars) bottom panel). Differences between groups were determined using the paired Student $t$ test. (E) Primary MCL cells were treated with dasatinib for $24 \mathrm{~h}$ with various concentrations (top panel) or with 100nM (middle panel). Apoptosis was measured as described above. Results are also shown as median \pm quartile (box) \pm SE (bars) bottom panel). 
A

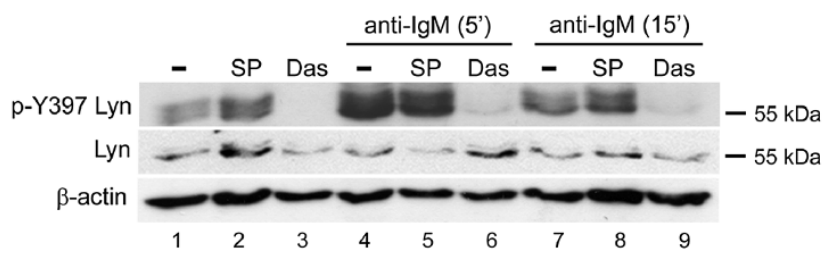

B

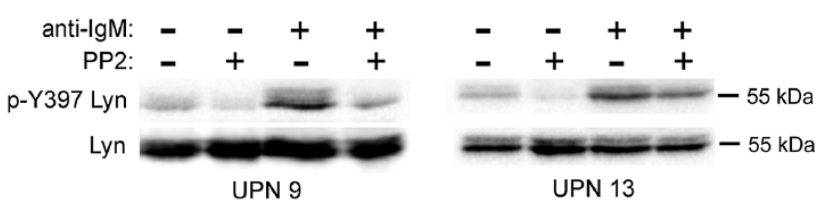

C
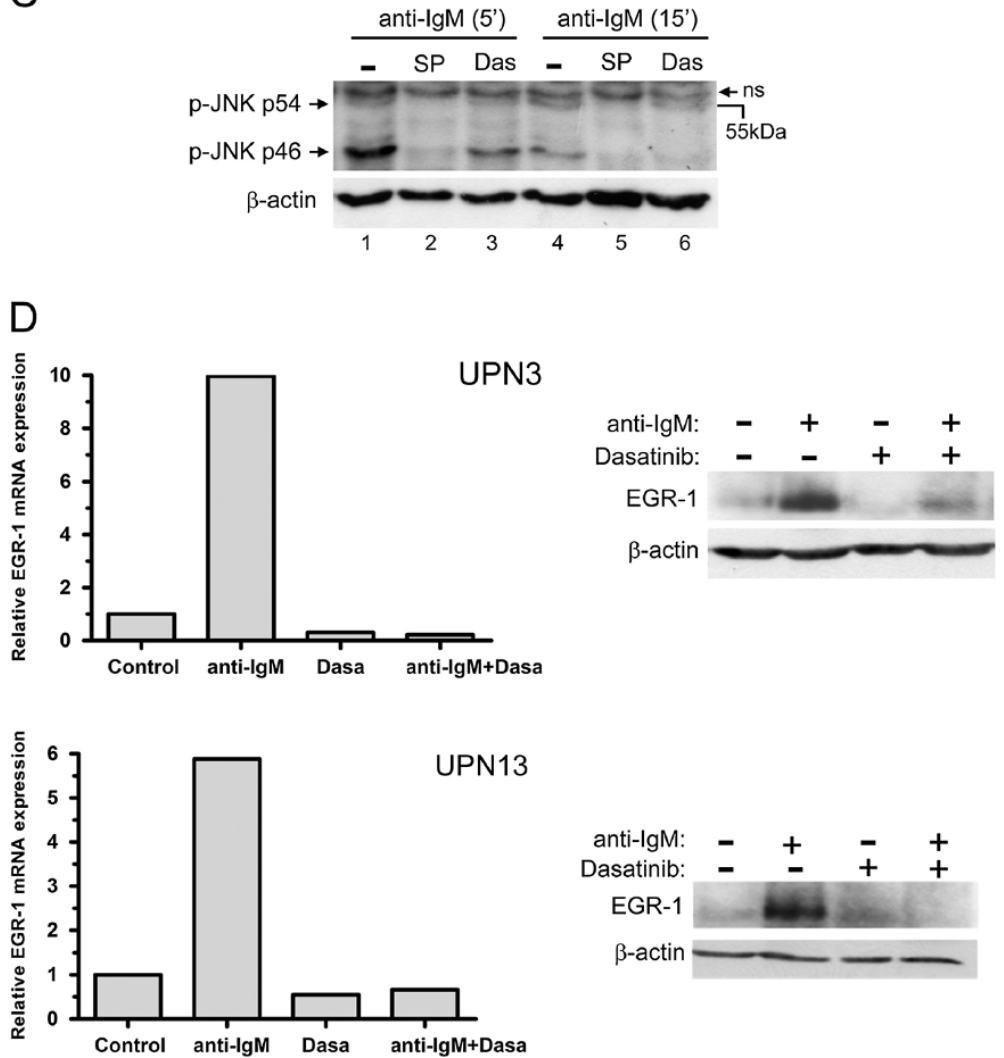

Figure 5 PP2 and dasatinib inhibit BCR-induced LYN and JNK activation and EGR-1 upregulation. (A) Patients' cells (UPN9) were

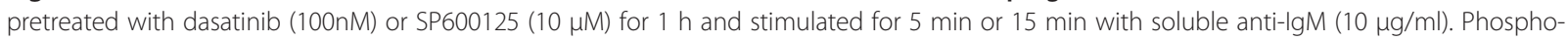
Tyr397 LYN was detected using a pan phospho-src family antibody. (B) The same experiment was done with PP2 (10 HM) on UPN 9 and UPN 13 under the same conditions of BCR stimulation for 10 min. Lines 1 and 2 have to be compared to evidence the effect of PP2 on the constitutive level of phosphorylation for Lyn. Similarly lines 3 and 4 reflect this effect upon BCR stimulation. (C) BCR-induced phospho-JNK (p54 and p46) was analyzed under treatment with dasatinib (100nM) or SP600125 (10 $\mu \mathrm{M})$ used herein as a positive control of phospho-JNK inhibition. (D) Impact of dasatinib on BCR-induced EGR-1 expression. MCL cells were pretreated with various concentrations of dasatinib as indicated and stimulated with immobilized anti-IgM. EGR-1 mRNA and protein were analyzed by qRT-PCR at $1 \mathrm{~h}$ of stimulation (left panel) and western-blot at $3 \mathrm{~h}$ of stimulation (right panel). Relative mRNA expression was calculated compared with unstimulated cells. 


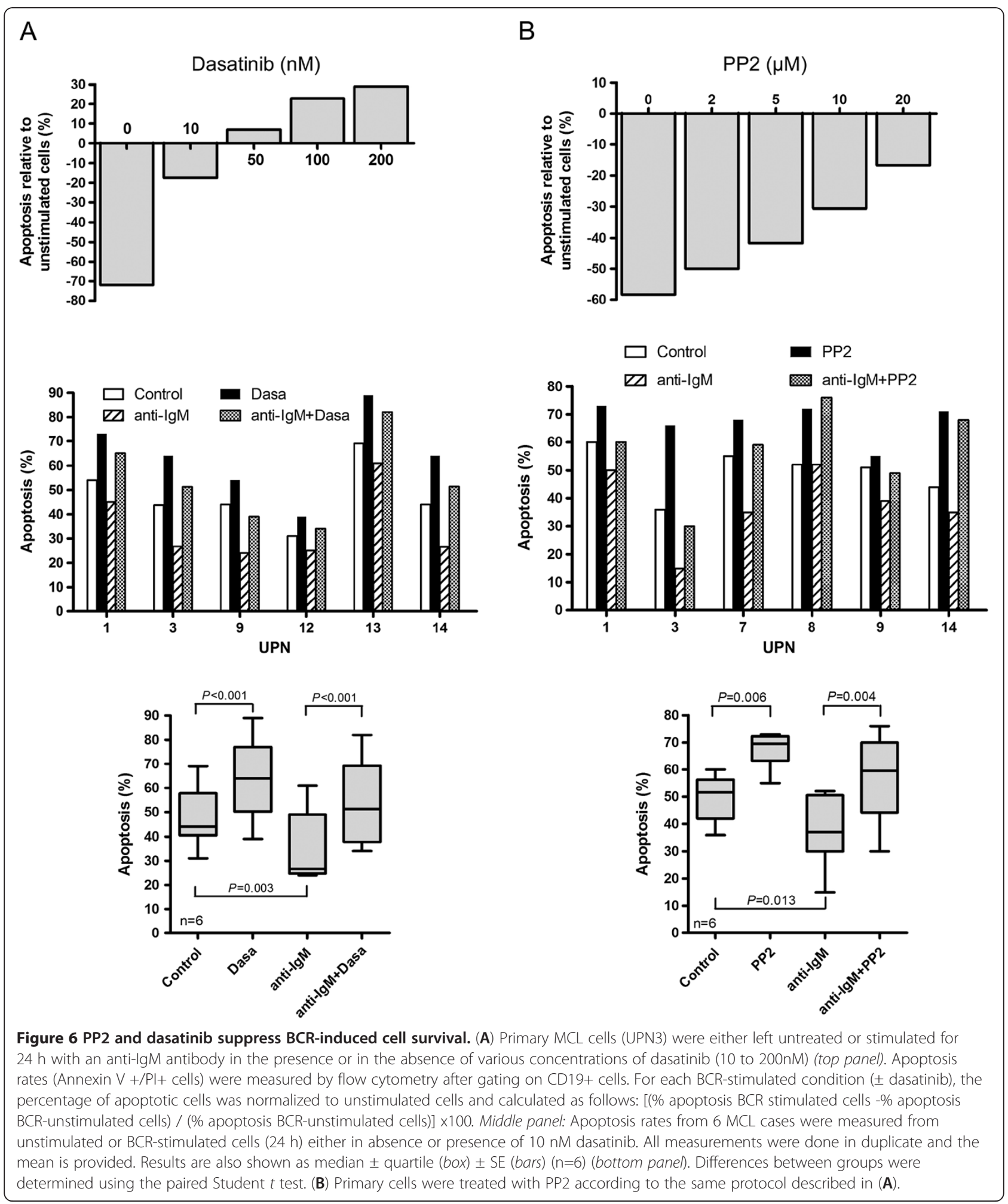

like CD44, NF-kB1, thymidine kinase, cyclin D1 and platelet-derived growth factor that are important for cell survival and proliferation [23,33-35]. We thus evaluated the role of EGR-1 in MCL cell survival and showed that inhibition of JNK by SP600125 induced a decrease of constitutive and BCR-induced EGR-1 expression, associated with an increase of apoptosis and a suppression of BCR-induced survival. We confirmed the JNKdependent upregulation of EGR-1 by blocking the activity of TAK1, the upstream activator of JNK, which was 
recently described to play an essential role in MCL survival [36]. Our results indicate that in MCL cells, EGR-1 is a downstream target of BCR signaling and its expression can be enhanced in response to antigen stimulation leading to cell survival. In addition to EGR-1, we observed that the BCR engagement also led to an increase of c-MYC in patients' cells only. This differential response between cell lines and primary cells might reflect higher levels of c-MYC expression in cell lines as compared to patient's cells [37]. Cell lines might therefore become unresponsive to further stimulation through the BCR. The delayed kinetic induction of cMyc as compared to EGR-1 in patient's cells might argue for a latter induction of c-Myc. Whether this induction is related to expression of EGR-1 as proposed in CLL [38] and BKS2 cells activated by CpG ODN [39] remains to be determined. Nevertheless, our results suggest that EGR-1 and c-MYC upregulations could play an essential role in BCR-induced survival of MCL cells.

The importance of BCR signaling in MCL was recently investigated using a high-throughput phospho-proteomic technique which identified more than 300 tyrosinephosphorylated proteins [15]. The most abundant peptides were part of proteins constituting the BCR-associated signalosome. Among them, the kinases LYN and SYK were found to be constitutively strongly phosphorylated, thus reflecting an active BCR signaling even in absence of antigen stimulation. The importance of the BCR signaling in MCL was also suggested through the activation of SYK probably due to a constitutively activated signalosome made of LYN and CSK-binding protein/phosphoprotein associated with glycosphingolipid-enriched microdomains (Cbp/PAG) membrane adaptor [6,40]. In the present study, we showed in a subset of primary MCL cells that LYN was in a constitutively active form as revealed by phosphorylation of the active Tyr397 LYN residue. LYN is believed to be a key component of cell membrane lipid rafts. Moreover, a subset of transmembrane proteins with aberrant expression was identified in MCL plasma membranes [41]. In particular, $\mathrm{Cbp} / \mathrm{PAG}$ that participates to the negative regulation of LYN in resting B cells through CSK recruitment was underexpressed in MCL primary cells compared to normal B cells. This low expression of Cbp/PAG could thus contribute to the constitutive activation of LYN in MCL cells.

Dasatinib, a dual BCR/ABL and SFK inhibitor, has demonstrated its efficacy in inhibiting cell proliferation of lymphoma B cells exhibiting a constitutive activation of Src kinase. Yang et al. demonstrated that inhibition of the Src-SYK-PLCg2 pathway by dasatinib induced G1 arrest in DLBCL [42]. In the present study, we evidenced a constitutive and BCR-induced phosphorylation of LYN, thus justifying the rationale to evaluate the impact of dasatinib in MCL cell survival. We showed that dasatinib, which targeted the ATP binding pocket of LYN [30], inhibited phosphorylation of Tyr397 LYN probably by blocking its trans-autophosphorylation. .We also showed for the first time that dasatinib induced apoptosis of primary MCL cells and suppressed BCRinduced survival after antigen-triggering at nanomolar range. Of interest, the concentration levels of dasatinib (100nM) required to induce in vitro MCL cell apoptosis are in agreement with clinically achievable doses [43]. A phase II study of dasatinib in relapsed or refractory CLL showed partial responses in 3 of 15 patients and among the remaining 12 patients, five patients had nodal responses. The investigators thus concluded that dasatinib as a single agent had activity in relapsed and refractory CLL [44]. A phase I/II study of dasatinib is currently conducted by recruiting patients in relapsed or refractory non-hodgkin's lymphoma (NHL) including mantle cell lymphoma (NCT00550615).

\section{Conclusion}

In conclusion, this study performed on primary MCL lymphocytes evidenced a dysregulation of early BCR signaling characterized by a constitutive LYN phosphorylation which can be enhanced in response to BCR engagement. Furthermore, targeting proximal BCRassociated kinases efficiently induced apoptosis of MCL cells. Thus, inhibition of LYN kinase and downstream JNK/EGR-1 pathway could be a new therapeutic strategy in MCL to overcome pro-survival signal emanating from the BCR.

\section{Methods}

\section{MCL samples and cell lines}

Peripheral blood mononuclear cells were obtained from 14 MCL leukemic patients by Ficoll-Hypaque density gradient (Stem Cell Technologies, Grenoble, France). Lymphocytosis was greater than $8.0 \times 10^{9} / \mathrm{L}$ and 10 out of 14 samples contained at least $80 \%$ of B lymphocytes (Additional file 5 : Table S1). All B lymphocytes are monoclonal tumor B cells as evidenced through flow cytometry phenotyping of the surface immunoglobulin light chain (monotypic kappa or lambda). Seven cases (7/14) showed mutated IGHV and none of them displayed mutation in ITAM sequences of CD79B. The diagnosis of MCL was ascertained by immunophenotyping, cytogenetic and FISH analysis of $\mathrm{t}$ $(11 ; 14)$ and overexpression of cyclin D1 was detected by competitive RT-PCR according to the World Health Organization classification. All patients were homogeneously treated in a prospective trial of the GOELAMS group "Lymphome du manteau 2006 SA" [45]. All patients were provided written informed consent, validated by the Ethics Committee from the GOELAMS group, in accordance with the Declaration of Helsinki. Patients usually received treatment very quickly after sampling, making it 
difficulties to repeat all experiments several times on the same sample. Jeko-1, and Granta-519 cell lines were purchased from the German Collection of Microorganisms and Cell Cultures (DSMZ, Braunshwieig, Germany) and the HBL-2 cell line was a generous gift from Dr B. Sola (Caen, France) [46].

Patients' cells were either used freshly isolated or cryopreserved in liquid nitrogen in the presence of $10 \%$ dimethyl sulfoxide and 20\% heat-inactivated FCS. MCL leukemic cells $\left(3 \times 10^{6}\right.$ cells $\left./ \mathrm{ml}\right)$ were cultured in complete RPMI 1640 medium supplemented with 10\% heat-inactivated foetal calf serum. Jeko-1, HBL-2 and Granta-519 cell lines were maintained in culture in the same media. For BCR stimulation, plates were precoated with rabbit anti-human IgM antibody $(10 \mu \mathrm{g} / \mathrm{mL}$; Jackson ImmunoResearch, Baltimore, MD) as previously described [14] or the anti-IgM antibody was added to the culture medium at the same concentration for short stimulation time.

\section{Antibodies and reagents}

Antibodies to EGR-1 (mAb 44D5), c-MYC (mAb 9B11), phospho-Src family (mAb 100 F9) also reactive with phospho-Tyr397 LYN (catalytic site) and phospho-JNK (Thr183/Tyr185) were from Cell Signaling (Beverley, MA). Monoclonal mouse antibody (H-6) and polyclonal rabbit antibody (44) to LYN were from Santa-Cruz (Santa Cruz, CA). Anti-phosphotyrosine monoclonal antibody (clone 4 G10) was from Millipore (Billerica, MA). Dasatinib (Clini Sciences, Montrouge, France) was used at 100nM, unless otherwise stated. JNK inhibitor SP600125 and PP2 (4-Amino-3-(4-chlorophenyl)-1-(t-butyl)-1Hpyrazolo[3,4-d]pyrimidine) was from Sigma (Saint Quentin Fallavier, France) and (5Z)-7-Oxozeaenol (TAK1 inhibitor) was from Tocris Bioscience (Bristol, UK).

\section{$\mathrm{RT}^{2}$ profiler PCR arrays}

Tumor B-lymphocytes from MCL patients were purified by the RosetteSep ${ }^{\circledR}$ Human B Cell Enrichment Cocktail (Stemcell technologies, Grenoble, France). Cells were cultured for 3 hours upon BCR stimulation or left untreated. Total RNA were extracted and analyzed with "p53 signaling pathway" array (SA Biosciences PAHS027) according to the manufacturer's instructions (SA Biosciences, Frederick, MD) with an Applied Biosystems 7500 Fast Real-Time PCR Systems. Each gene expression was normalized to the mean $\mathrm{Ct}$ values from the four housekeeping genes available in the PCR array ( $\beta 2$-microglobulin, $\beta$-actin ribosomal protein L13A, hypoxanthine phosphorybosyl transferase- 1 and $\beta$-actin), then normalized to unstimulated control cells to determine the fold-change. Relative fold change of expression was calculated by the $\Delta \Delta \mathrm{Ct}$ method and the values are expressed as $2^{-\Delta \Delta \mathrm{Ct}}$. All points were done in duplicate.

\section{Apoptosis assay}

Cell apoptosis was evaluated using flow cytometry (FACSCantoTM II Becton Dickinson) on leukemic MCL PBMC after gating on CD19+ cells using Annexin V-FITC and propidium iodide staining (BD Biosciences, San Jose, CA). Percentage of apoptotic cells corresponded to $\%$ of annexin V-positive, including PI-negative and PI-positive cells. All measurements were done in duplicate and the mean is indicated.

\section{Quantification of EGR-1 and c-MYC mRNA by qRT-PCR}

RNA from unstimulated or anti-IgM stimulated cells were extracted using RNeasy Mini kit (QIAGEN) and EGR-1 and c-MYC expressions were analyzed by qRT-PCR using SYBR Green reagents. Results were normalized to the mean $\mathrm{Ct}$ values from cyclophilin A housekeeping gene then normalized to unstimulated control cells to determine the fold change. Relative fold change of expression was calculated by the $\Delta \Delta \mathrm{Ct}$ method and the values are expressed as $2^{-\Delta \Delta \mathrm{Ct}}$. All points were done in duplicate. The primers used for amplification (Sigma-Aldrich) were as follows:

EGR-1 forward primer
$\left(5^{\prime}\right.$ CGAGCAGCCCTACGAGCACCTGAC3'),
EGR-1 reverse primer
$\left(5^{\prime}\right.$ TGCGCAGCTCAGGGGTGGGCTCTG3'),
c-MYC forward primer
$\left(5^{\prime}\right.$ GCTGCTTAGACGCTGGATTTTT3'),
c-MYC reverse primer
$\left(5^{\prime}\right.$ ACCGAGTCGTAGTCGAGGTCAT3'),
cyclophilin A forward primer
(5'GCACTGGAGAGAAAGGATTTGG3') and
cyclophilin A reverse primer
(5'AGTGCCATTATGGCGTGTGA3').

\section{Western blotting and immunoprecipitation}

Total protein extracts from $3 \times 10^{6} \mathrm{MCL}$ cells (PBMC) were separated on $10 \%$ polyacrylamide denaturing gel, transferred to a nitrocellulose membrane and incubated overnight with the appropriate antibody followed by a secondary horseradish peroxidase-conjugated antibody (Bio-Rad). Detection was performed using ECL (Amersham Biosciences, Buckinghamshire, UK) and autoradiography (Biomax, Kodak, Rochester, USA). For LYN immunoprecipitation, HBL-2 cells were lysed in 1\% Nonidet P-40 (NP-40) lysis buffer for 30 minutes on ice. Insoluble material was removed by centrifugation at $27000 \mathrm{~g}$ for 10 minutes at $4^{\circ} \mathrm{C}$ and soluble proteins were immunoprecipitated with a rabbit anti-LYN (H-6) antibody for 2 hours at $4^{\circ} \mathrm{C}$. Immunocomplexes were solubilized in SDS sample buffer, analyzed on SDS-PAGE, transferred and subjected to immunoblotting as described above using either a mouse anti- 
phosphotyrosine antibody (clone 4 G10) or a mouse antiLYN (44) antibody.

\section{siRNA assay}

Three million cells were resuspended in $100 \mu \mathrm{L}$ of Human B Cell Lymphoma Nucleofector ${ }^{\circledR}$ Kit (Amaxa) containing either $1 \mu \mathrm{M}$ of EGR-1 siRNA (On-Target plus SMART pool Human EGR-1, Dharmacon) or $1 \mu \mathrm{M}$ of control siRNA (Ctrl1: On-Target plus nontargeting pool; Ctrl2: On-target plus non-targeting siRNA\#1; Dharmacon). Cells were transfected in a Nucleofector II device (Lonza) by using U-015 program, transferred to culture plates and western blot and apoptosis assays were performed as described above.

\section{Statistical analyses}

Differences between groups were determined using the Student's $t$ test. Statistical analyses were performed using GraphPad Prism software (San Diego, CA). P values below 0.05 were considered statistically significant.

\section{Additional files}

Additional file 1: Table S2. Differentially expressed genes in BCRstimulated MCL cells ( 3 h) compared with unstimulated cells.

Additional file 2: Figure S1. Inhibition of TAK1 protein by (5Z)-7Oxozeaenol suppressed BCR-induced EGR1 expression. HBL2 cells were pretreated with (5Z)-7-Oxozeaenol (5Z-7-oxo) $(0.3$ and $0.5 \mu \mathrm{M})$ for $1 \mathrm{~h}$ and then stimulated with immobilized anti-lgM $(10 \mu \mathrm{g} / \mathrm{ml})$. Total protein extracts were analysed by western-blot for EGR1 expression.

Additional file 3: Figure S2. Constitutive phosphorylation of LYN in primary MCL cells. Total protein from UPN1, UPN5, UPN13 and UPN14 were extracted and analysed by western blot. Phospho-Tyr397 LYN was detected using a pan phospho-src family antibody. The blots were stripped and re-probed for total LYN.

Additional file 4: Figure S3. Dasatinib treatment suppresses BCRinduced upregulation of EGR-1 protein. HBL-2 cells were pretreated (1 h) with various concentrations of Dasatinib (1nM-200nM) and stimulated with immobilized anti-lgM for $1 \mathrm{~h}$ (anti-lgM) or left unstimulated (-). EGR1 protein level was then analysed by western blot.

Additional file 5: Table S1. Characteristics of the $14 \mathrm{MCL}$ cases (UPN).

\section{Abbreviations}

MCL: Mantle cell lymphoma; SFK: Src family kinase; BCR: B-cell receptor; JNK: c-JUN NH2-terminal kinase; EGR-1: Early growth response gene-1; IGHV: Immunoglobulin heavy chain variable-region; MAPK: Mitogen-activated protein kinases; ERK: Extracellular signal-regulated kinase; CLL: Chronic lymphocytic leukemia; DLBCL: Diffuse large B cell lymphoma; PBMC: Peripheral blood mononuclear cells; TAK1: Transforming growth factor- $\beta$ activated kinase-1; ITAM: Immunoreceptor tyrosine-based activation motif; SYK: Spleen tyrosine kinase; MYC: Myelocytomatosis; SH2: Srchomology 2; PLC: Phospholipase C; PKC: Protein kinase C; IL: Interleukin; STAT3: Signal transducer and activator of transcription 3.

\section{Competing interests}

The authors declare that they have no conflict of interest.

\section{Authors' contribution}

$M B, J T, C R$ performed research. $R G, A M$ provided reagents and members of the GOELAMS group. NVB and FC contributed reagents and helped to design the study and to write the manuscript. DL designed research, analyzed results, made the figures and wrote the manuscript. FBM designed research, performed experiments, analyzed results, made the figures and wrote the manuscript. All authors read and approved the final manuscript.

\section{Authors' information}

This work was supported by the GOELAMS group (Groupe Ouest-Est des Leucémies Aiguës et Maladies du Sang.) and by the Institut National du Cancer (INCA) for the tumor biobank. M.A.B. was supported by the Société Française d'Hématologie (SFH).

FBM and DL are co-senior authors.

\section{Author details}

${ }^{1}$ INSERM, UMR U978, Adaptateur de Signalisation en Hématologie, Bobigny F-93000, France. 2Université Paris 13, Sorbonne Paris Cité, Labex INFLAMEX, Bobigny F-93000, France. ${ }^{3}$ AP-HP, Service d'hématologie biologique, Hôpital Avicenne, Bobigny F-93000, France. ${ }^{4}$ AP-HP, Service d'Anatomopathologie, Hôpital Avicenne, Bobigny F-93000, France. ${ }^{5}$ INSERM, U823, Université Joseph Fourier, Institut Albert Bonniot, Grenoble F-38000, France. ${ }^{6} \mathrm{CHU}$ de Grenoble, Service d'hématologie clinique, Grenoble F-38000, France. ${ }^{7}$ French GOELAMS Group, UMR U978 INSERM-Université Paris 13, UFR SMBH, 74 rue Marcel Cachin, Bobigny 93000, France.

Received: 5 February 2013 Accepted: 5 February 2013

Published: 19 February 2013

\section{References}

1. Fernandez V, Salamero O, Espinet B, Sole F, Royo C, Navarro A, Camacho F, Bea S, Hartmann E, Amador V, Hernandez L, Agostinelli C, Sargent RL, Rozman M, Aymerich M, Colomer D, Villamor N, Swerdlow SH, Pileri SA, Bosch F, Piris MA, Montserrat E, Ott G, Rosenwald A, Lopez-Guillermo A, Jares P, Serrano S, Campo E: Genomic and gene expression profiling defines indolent forms of mantle cell lymphoma. Cancer Res 2010, 70:1408-1418.

2. Hofmann WK, de Vos S, Tsukasaki K, Wachsman W, Pinkus GS, Said JW, Koeffler HP: Altered apoptosis pathways in mantle cell lymphoma detected by oligonucleotide microarray. Blood 2001, 98:787-794.

3. Martinez N, Camacho Fl, Algara P, Rodriguez A, Dopazo A, Ruiz-Ballesteros E, Martin P, Martinez-Climent JA, Garcia-Conde J, Menarguez J, Solano F, Mollejo M, Piris MA: The molecular signature of mantle cell lymphoma reveals multiple signals favoring cell survival. Cancer Res 2003, 63:8226-8232

4. Ortega-Paino E, Fransson J, Ek S, Borrebaeck CA: Functionally associated targets in mantle cell lymphoma as defined by DNA microarrays and RNA interference. Blood 2008, 111:1617-1624.

5. Pinyol M, Bea S, Pla L, Ribrag V, Bosq J, Rosenwald A, Campo E, Jares P. Inactivation of RB1 in mantle-cell lymphoma detected by nonsensemediated mRNA decay pathway inhibition and microarray analysis. Blood 2007, 109:5422-5429.

6. Rinaldi A, Kwee I, Taborelli M, Largo C, Uccella S, Martin V, Poretti G, Gaidano G, Calabrese G, Martinelli G, Baldini L, Pruneri G, Capella C, Zucca E, Cotter FE, Cigudosa JC, Catapano CV, Tibiletti MG, Bertoni F: Genomic and expression profiling identifies the B-cell associated tyrosine kinase Syk as a possible therapeutic target in mantle cell lymphoma. Br J Haematol 2006, 132:303-316

7. Rizzatti EG, Falcao RP, Panepucci RA, Proto-Siqueira R, Anselmo-Lima WT, Okamoto OK, Zago MA: Gene expression profiling of mantle cell lymphoma cells reveals aberrant expression of genes from the PI3K-AKT, WNT and TGFbeta signalling pathways. Br J Haematol 2005, 130:516-526.

8. Rosenwald A, Wright G, Wiestner A, Chan WC, Connors JM, Campo E, Gascoyne RD, Grogan TM, Muller-Hermelink HK, Smeland EB, Chiorazzi M, Giltnane JM, Hurt EM, Zhao H, Averett L, Henrickson S, Yang L, Powell J, Wilson WH, Jaffe ES, Simon R, Klausner RD, Montserrat E, Bosch F, Greiner TC, Weisenburger DD, Sanger WG, Dave BJ, Lynch JC, Vose J, Armitage JO, Fisher RI, Miller TP, LeBlanc M, Ott G, Kvaloy S, Holte H, Delabie J, Staudt LM: The proliferation gene expression signature is a quantitative integrator of oncogenic events that predicts survival in mantle cell lymphoma. Cancer Cell 2003, 3:185-197.

9. Thieblemont C, Nasser V, Felman P, Leroy K, Gazzo S, Callet-Bauchu E, Loriod B, Granjeaud S, Gaulard P, Haioun C, Traverse-Glehen A, Baseggio L, Bertucci F, Birnbaum D, Magrangeas F, Minvielle S, Avet-Loiseau H, Salles G, 
Coiffier B, Berger F, Houlgatte R: Small lymphocytic lymphoma, marginal zone B-cell lymphoma, and mantle cell lymphoma exhibit distinct geneexpression profiles allowing molecular diagnosis. Blood 2004, 103:2727-2737.

10. Davis RE, Ngo VN, Lenz G, Tolar P, Young RM, Romesser PB, Kohlhammer $H_{\text {, }}$ Lamy L, Zhao H, Yang Y, Xu W, Shaffer AL, Wright G, Xiao W, Powell J, Jiang JK, Thomas CJ, Rosenwald A, Ott G, Muller-Hermelink HK, Gascoyne RD, Connors JM, Johnson NA, Rimsza LM, Campo E, Jaffe ES, Wilson WH, Delabie J, Smeland EB, Fisher Rl, Braziel RM, Tubbs RR, Cook JR, Weisenburger DD, Chan WC, Pierce SK, Staudt LM: Chronic active B-cell -receptor signalling in diffuse large B-cell lymphoma. Nature 2010, 463:88-92.

11. Deglesne PA, Chevallier N, Letestu R, Baran-Marszak F, Beitar T, Salanoubat C, Sanhes L, Nataf J, Roger C, Varin-Blank N, Ajchenbaum-Cymbalista F: Survival response to B-cell receptor ligation is restricted to progressive chronic lymphocytic leukemia cells irrespective of Zap70 expression. Cancer Res 2006, 66:7158-7166.

12. Kuppers R: Mechanisms of B-cell lymphoma pathogenesis. Nat Rev Cancer 2005, 5:251-262

13. Rodriguez A, Villuendas R, Yanez L, Gomez ME, Diaz R, Pollan M, Hernandez N, de la Cueva P, Marin MC, Swat A, Ruiz E, Cuadrado MA, Conde E, Lombardia L, Cifuentes F, Gonzalez M, Garcia-Marco JA, Piris MA: Molecular heterogeneity in chronic lymphocytic leukemia is dependent on $B C R$ signaling: clinical correlation. Leukemia 2007, 21:1984-1991.

14. Baran-Marszak F, Boukhiar M, Harel S, Laguillier C, Roger C, Gressin R, Martin A, Fagard R, Varin-Blank N, Ajchenbaum-Cymbalista F, Ledoux D: Constitutive and B-cell receptor-induced activation of STAT3 are important signaling pathways targeted by bortezomib in leukemic mantle cell lymphoma. Haematologica 2010, 95:1865-1872.

15. Pighi C, Gu TL, Dalai I, Barbi S, Parolini C, Bertolaso A, Pedron S, Parisi A, Ren J, Cecconi D, Chilosi M, Menestrina F, Zamo A: Phospho-proteomic analysis of mantle cell lymphoma cells suggests a pro-survival role of B-cell receptor signaling. Cell 2011, 34:141-153.

16. Hadzidimitriou A, Agathangelidis A, Darzentas N, Murray F, Delfau-Larue MH, Pedersen LB, Lopez AN, Dagklis A, Rombout P, Beldjord K, Kolstad A, Dreyling MH, Anagnostopoulos A, Tsaftaris A, Mavragani-Tsipidou P, Rosenwald A, Ponzoni M, Groenen P, Ghia P, Sander B, Papadaki T, Campo E, Geisler C, Rosenquist R, Davi F, Pott C, Stamatopoulos K: Is there a role for antigen selection in mantle cell lymphoma? Immunogenetic support from a series of 807 cases. Blood 2011, 118:3088-3095.

17. Pierce SK, Liu W: The tipping points in the initiation of B cell signalling: how small changes make big differences. Nat Rev Immunol 2010, 10:767-777.

18. Platanias LC: Map kinase signaling pathways and hematologic malignancies. Blood 2003, 101:4667-4679.

19. Alizadeh AA, Eisen MB, Davis RE, Ma C, Lossos IS, Rosenwald A, Boldrick JC, Sabet H, Tran T, Yu X, Powell Jl, Yang L, Marti GE, Moore T, Hudson J Jr, Lu L, Lewis DB, Tibshirani R, Sherlock G, Chan WC, Greiner TC, Weisenburger DD, Armitage JO, Warnke R, Levy R, Wilson W, Grever MR, Byrd JC, Botstein D, Brown PO, Staudt LM: Distinct types of diffuse large B-cell lymphoma identified by gene expression profiling. Nature 2000, 403:503-511.

20. Hideshima T, Hayashi T, Chauhan D, Akiyama M, Richardson P, Anderson K: Biologic sequelae of c-Jun $\mathrm{NH}(2)$-terminal kinase (JNK) activation in multiple myeloma cell lines. Oncogene 2003, 22:8797-8801.

21. Wang M, Atayar C, Rosati S, Bosga-Bouwer A, Kluin P, Visser L: JNK is constitutively active in mantle cell lymphoma: cell cycle deregulation and polyploidy by JNK inhibitor SP600125. J Pathol 2009, 218:95-103.

22. Ke J, Gururajan M, Kumar A, Simmons A, Turcios L, Chelvarajan RL, Cohen DM, Wiest DL, Monroe JG, Bondada S: The role of MAPKs in B cell receptor-induced down-regulation of Egr-1 in immature $B$ lymphoma cells. J Biol Chem 2006, 281:39806-39818.

23. Muthukkumar S, Han SS, Rangnekar VM, Bondada S: Role of Egr-1 gene expression in B cell receptor-induced apoptosis in an immature B cell lymphoma. J Biol Chem 1997, 272:27987-27993.

24. Forsdyke DR: CDNA cloning of mRNAS which increase rapidly in human lymphocytes cultured with concanavalin-A and cycloheximide. Biochem Biophys Res Commun 1985, 129:619-625.
25. Wang Z, Morris DL, Rothstein TL: Constitutive and inducible levels of egr-1 and c-myc early growth response gene expression in self-renewing B-1 lymphocytes. Cell Immunol 1995, 162:309-314.

26. DeLigio JT, Zorio DA: Early growth response 1 (EGR1): a gene with as many names as biological functions. Cancer Biol Ther 2009, 8:1889-1892.

27. Gururajan M, Chui R, Karuppannan AK, Ke J, Jennings CD, Bondada S: C-Jun $\mathrm{N}$-terminal kinase (JNK) is required for survival and proliferation of $\mathrm{B}$ lymphoma cells. Blood 2005, 106:1382-1391.

28. Tauzin S, Ding H, Burdevet D, Borisch B, Hoessli DC: Membrane-associated signaling in human B-lymphoma lines. Exp Cell Res 2011, 317:151-162.

29. Sato S, Sanjo H, Takeda K, Ninomiya-Tsuji J, Yamamoto M, Kawai T, Matsumoto K, Takeuchi O, Akira S: Essential function for the kinase TAK1 in innate and adaptive immune responses. Nat Immunol 2005, 6:1087-1095.

30. Williams NK, Lucet IS, Klinken SP, Ingley E, Rossjohn J: Crystal structures of the Lyn protein tyrosine kinase domain in its Apo- and inhibitor-bound state. J Biol Chem 2009, 284:284-291.

31. Gomez-Martin D, Diaz-Zamudio M, Galindo-Campos M, Alcocer-Varela J: Early growth response transcription factors and the modulation of immune response: implications towards autoimmunity. Autoimmun Rev 2009, 9:454-458.

32. Seyfert VL, McMahon S, Glenn W, Cao XM, Sukhatme VP, Monroe JG: Egr-1 expression in surface Ig-mediated B cell activation. Kinetics and association with protein kinase C activation. J Immunol 1990, 145:3647-3653.

33. Gashler A, Sukhatme VP: Early growth response protein 1 (Egr-1): prototype of a zinc-finger family of transcription factors. Prog Nucleic Acid Res Mol Biol 1995, 50:191-224.

34. Maltzman JS, Carman JA, Monroe JG: Role of EGR1 in regulation of stimulus-dependent CD44 transcription in B lymphocytes. Mol Cell Biol 1996, 16:2283-2294.

35. McMahon SB, Monroe JG: The role of early growth response gene 1 (egr-1) in regulation of the immune response. J Leukoc Biol 1996, 60:159-166.

36. Buglio D, Palakurthi S, Byth K, Vega F, Toader D, Saeh J, Neelapu SS, Younes A: Essential role of TAK1 in regulating mantle cell lymphoma survival. Blood 2012, 120:347-355.

37. Tagawa H, Karnan S, Suzuki R, Matsuo K, Zhang X, Ota A, Morishima Y, Nakamura S, Seto M: Genome-wide array-based CGH for mantle cell lymphoma: identification of homozygous deletions of the proapoptotic gene BIM. Oncogene 2005, 24:1348-1358.

38. Vallat LD, Park Y, Li C, Gribben JG: Temporal genetic program following Bcell receptor cross-linking: altered balance between proliferation and death in healthy and malignant B cells. Blood 2007, 109:3989-3997.

39. Han SS, Chung ST, Robertson DA, Chelvarajan RL, Bondada S: CpG oligodeoxynucleotides rescue BKS-2 immature B cell lymphoma from anti-lgM-mediated growth inhibition by up-regulation of egr-1. Int Immunol 1999, 11:871-879.

40. Tauzin S, Ding H, Khatib K, Ahmad I, Burdevet D, van Echten-Deckert G, Lindquist JA, Schraven B, Din NU, Borisch B, Hoessli DC: Oncogenic association of the $\mathrm{Cbp} / \mathrm{PAG}$ adaptor protein with the Lyn tyrosine kinase in human B-NHL rafts. Blood 2008, 111:2310-2320.

41. Boyd RS, Jukes-Jones R, Walewska R, Brown D, Dyer MJ, Cain K: Protein profiling of plasma membranes defines aberrant signaling pathways in mantle cell lymphoma. Mol Cell Proteomics 2009, 8:1501-1515.

42. Yang C, Lu P, Lee FY, Chadburn A, Barrientos JC, Leonard JP, Ye F, Zhang D, Knowles DM, Wang YL: Tyrosine kinase inhibition in diffuse large B-cell lymphoma: molecular basis for antitumor activity and drug resistance of dasatinib. Leukemia 2008, 22:1755-1766.

43. Luo FR, Yang Z, Camuso A, Smykla R, McGlinchey K, Fager K, Flefleh C, Castaneda S, Inigo I, Kan D, Wen ML, Kramer R, Blackwood-Chirchir A, Lee FY: Dasatinib (BMS-354825) pharmacokinetics and pharmacodynamic biomarkers in animal models predict optimal clinical exposure. Clin Cancer Res 2006, 12:7180-7186.

44. Amrein PC, Attar EC, Takvorian T, Hochberg EP, Ballen KK, Leahy KM, Fisher DC, Lacasce AS, Jacobsen ED, Armand P, Hasserjian RP, Werner L, Neuberg D, Brown JR: Phase II study of dasatinib in relapsed or refractory chronic lymphocytic leukemia. Clin Cancer Res 2011, 17:2977-2986. 
45. Houot R, Le Gouill S, Ojeda Uribe M, Mounier C, Courby S, Dartigeas C, Bouabdallah K, Alexis Vigier M, Moles MP, Tournilhac O, Arakelyan N, Rodon P, El Yamani A, Sutton L, Fornecker L, Assouline D, Harousseau JL, Maisonneuve H, Caulet-Maugendre S, Gressin R: Combination of rituximab, bortezomib, doxorubicin, dexamethasone and chlorambucil (RiPAD+C) as first-line therapy for elderly mantle cell lymphoma patients: results of a phase II trial from the GOELAMS. Ann Oncol 2012, 23:1555-1561.

46. Peng HW, Chong LL, Chiang H, Chiang BN: Establishment and characterization of a new human lymphoma-derived cell line-HBL-2. Zhonghua Min Guo Wei Sheng Wu Ji Mian Yi Xue Za Zhi 1985, 18:79-85.

doi:10.1186/2162-3619-2-4

Cite this article as: Boukhiar et al:: Targeting early B-cell receptor signaling induces apoptosis in leukemic mantle cell lymphoma. Experimental Hematology \& Oncology 2013 2:4.

\section{Submit your next manuscript to BioMed Central} and take full advantage of:

- Convenient online submission

- Thorough peer review

- No space constraints or color figure charges

- Immediate publication on acceptance

- Inclusion in PubMed, CAS, Scopus and Google Scholar

- Research which is freely available for redistribution 